\title{
ABO incompatibility: its impact on pregnancy and neonate
}

\author{
U. Nagashree ${ }^{1 *}$, Swetha P. ${ }^{1}$, Sumana Manohar ${ }^{1}$, Latha Kanchi Parthasarathy ${ }^{2}$
}

\begin{abstract}
${ }^{1}$ Department of Obstetrics and Gynecology, Apollo Womens Hospitals, Chennai, Tamil Nadu, India
${ }^{2}$ Department of Pediatrics and NICU, Apollo Childrens Hospitals, Chennai, Tamil Nadu, India
\end{abstract}

Received: 23 October 2018

Revised: 28 December 2018

Accepted: 11 January 2019

\author{
*Correspondence: \\ Dr. U. Nagashree, \\ E-mail: dr.nagashree@yahoo.com
}

Copyright: (c) the author(s), publisher and licensee Medip Academy. This is an open-access article distributed under the terms of the Creative Commons Attribution Non-Commercial License, which permits unrestricted non-commercial use, distribution, and reproduction in any medium, provided the original work is properly cited.

\begin{abstract}
ABO incompatibility is one of the most common cause of haemolytic disease of fetus and new-born (HDFN). The expression of $\mathrm{ABO}$ incompatibility in most of the cases is mild due to the lower expression of A and B Antigens on fetal red cells. ABO incompatibility has affected the first pregnancy and is milder in the subsequent pregnancies. However, we describe this case with unusually severe form of ABO incompatibility which had an effect not only in her first pregnancy but also in all her subsequent pregnancies, evident as recurrent abortions and both her neonates developed pathological jaundice requiring exchange transfusion. It also emphasizes the fact that $\mathrm{ABO}$ incompatibility is not always a benign condition and should be considered in all babies whose mothers have $\mathrm{O}$ blood group, even in the presence of a negative DAT. Anticipation of ABO incompatibility not only in the first pregnancy but also in the subsequent pregnancies is necessary. Early diagnosis with cord blood bilirubin can prevent neonatal morbidity.
\end{abstract}

Keywords: ABO incompatibility, Anemia, Hemolytic disease

\section{INTRODUCTION}

Haemolytic disease of fetus and new-born occurs most commonly in $\mathrm{ABO}$ and $\mathrm{Rh}$ incompatibility. The implementation of RhD immunoprophylaxis has reduced maternal D alloimmunization from $14 \%$ to $1-2 \%$ and further reduction up to $0.1 \%$ is seen by antenatal prophylaxis. ${ }^{1}$ Hence, ABO incompatibility has now become the single largest cause of HDFN in the western world. $^{2}$ Many Asian countries have identified alloantibodies other than anti D as a cause of moderate to severe haemolytic disease. ${ }^{3,4} \mathrm{ABO}$ and $\mathrm{Rh}$ incompatibility can be differentiated by their presentation. (Table 1). Theoretically, selection in ABO incompatibility may operate at various stages from fertilization through pregnancy. ${ }^{5}$

It may extend its impact on the neonate. It produces a spectrum of haemolytic disease extending from cases in which there is little laboratory evidence of erythrocyte sensitization, haemolysis to cases of severe haemolytic disease.

Table 1: Comparison of $\mathrm{Rh}$ and $\mathrm{ABO}$ incompatibility.

\begin{tabular}{|l|l|l|}
\hline Frequency & Less common & More common \\
\hline Blood group & & \\
\hline Mother & Rh negative & O \\
\hline Fetus & Rh positive & A or B \\
\hline $\begin{array}{l}\text { Pregnancy } \\
\text { affected }\end{array}$ & Usually second & Usually first \\
\hline Severity & Severe & Mild \\
\hline Blood smear & Erythroblastosis & Spherocytosis \\
\hline DCT & $\begin{array}{l}\text { Strongly positive } \\
\text { Rh immune }\end{array}$ & $\begin{array}{l}\text { Weakly positive } \\
\text { or negative }\end{array}$ \\
\hline Prevention & $\begin{array}{l}\text { Rot available } \\
\text { globulin }\end{array}$ & Not \\
\hline
\end{tabular}


Clinically, significant jaundice $>12 \mathrm{mg} / \mathrm{dl}$ occurs in only $4 \%$ of such pregnancies. Disease is mild in most of the cases manifesting as neonatal hyperbilirubinemia within 24 hours of life which can be managed with phototherapy alone. An exchange transfusion is necessitated in only 1 in 1000 to 1 in 4000 pregnancies. Kernicterus can occur with an early onset and rapidly rising hyperbilirubinemia unless recognized. ${ }^{3}$

\section{CAES REPORT}

A 38-year-old $\mathrm{G}_{6} \mathrm{P}_{1} \mathrm{~L}_{1} \mathrm{~A}_{4}$ at 37 weeks 3 days gestation. She has been married for 12 years and it's a nonconsanguineous marriage. Her blood group is $\mathrm{O}$ positive. She has no medical comorbidities. Both her parents are diabetic and hypertensive. Her first conception was in 2007, it was a spontaneous abortion at 2 months of amenorrhea and dilatation and Curettage done. The second was a natural conception in 2010 and she delivered a girl baby of $2.7 \mathrm{~kg}$ by a normal vaginal delivery. The baby developed neonatal jaundice, kernicterus and exchange transfusion was done. The child had developmental delay. The child was extensively investigated for the cause of jaundice and it was attributed to $\mathrm{ABO}$ incompatibility. The third, fourth and fifth conceptions were spontaneous abortions at early weeks of gestation. The present pregnancy was a natural conception and the antenatal period was uneventful. She was admitted at 37weeks gestation in latent labor, she was taken up for LSCS on patient's request after covering prophylactic steroids. She delivered an alive boy baby weighing $2.65 \mathrm{~kg}$ with Apgar 8/10;9/10. Delayed cord clamping was done, and post-operative period was uneventful. In view of sibling having history of severe neonatal jaundice, cord blood serum bilirubin was measured and was high $(4.5 \mathrm{mg} / \mathrm{dl})$ and triple surface phototherapy was started. Baby's blood group was found to be A Positive and DCT was negative. Further serial serum bilirubin values done at $6^{\text {th }}$ hourly intervals showed a steady increase reaching up to $6.6 \mathrm{mg} / \mathrm{dl}$, IV immunoglobulin therapy was started and double volume exchange transfusion with $\mathrm{O}$ negative blood was done at 15 hours of life (Figure 1).

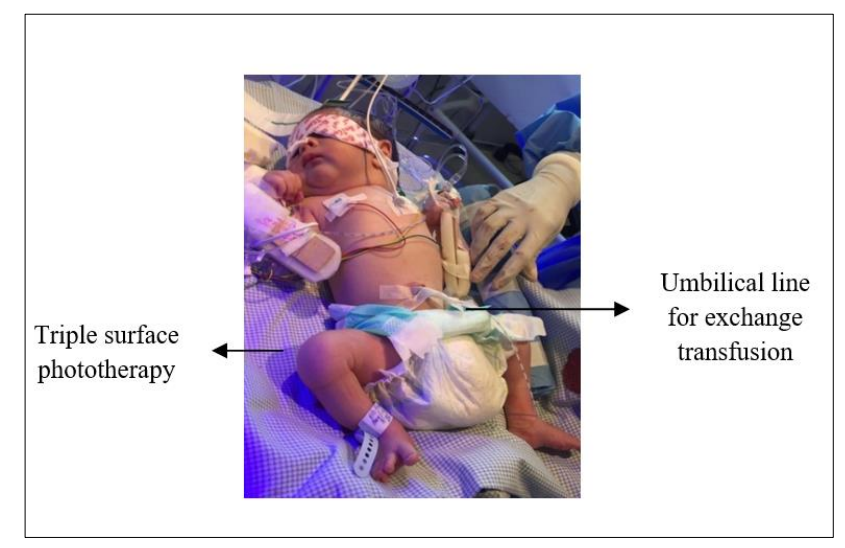

Figure 1: Neonate on phototherapy and exchange transfusion.
Post exchange levels of bilirubin were at an acceptable level and phototherapy was continued till 3 days of life. Screening for Inborn errors of metabolism-flowing panel and tests for jaundice within 24 hours was done. Everything was negative. Baby was discharged after 3 days of phototherapy. Follow up bilirubin was normal, done till 30 days of life. Neurological examination and hearing screening test were normal. The pathological jaundice in this infant was most probably due to ABO incompatibility. Further follow up at 3 months, 6 months and 1 year was advised.

\section{DISCUSSION}

Hemolytic disease of fetus and newborn occurs when there is trans-placental passage of maternal antibodies resulting in hemolysis of fetal/neonatal red cells. Implicated $\mathrm{Ab}$ could be naturally occurring (Anti A, Anti B) or immune antibodies developed following sensitization. This occurs in $15-20 \%$ of all pregnancies. This hemolytic process results in fetal anemia/hyperbilirubinemia in $10 \%$ of the cases.

ABO incompatibility mostly occurs exclusively in infants of blood group $\mathrm{A}$ or $\mathrm{B}$ born to $\mathrm{O}$ group mothers because IgG anti A, anti B occur more commonly in $\mathrm{O}$ group than group $\mathrm{A}$ or $\mathrm{B}$ individuals. An ABO incompatible mating in which father is $\mathrm{A}$, mother is $\mathrm{O}$; may produce a compatible $\mathrm{O}$ or an incompatible $\mathrm{A}$ fetus. $\mathrm{ABO}$ incompatibility may lead to fetal hemolysis in the first pregnancy because of preexisting antibodies in mother from infancy.

The incidence of $\mathrm{O}$ type mothers with $\mathrm{ABO}$ incompatibility most likely to have a spontaneous abortion (between 40 days to 135 days) in British Columbia. Several other studies examined relationship between $\mathrm{ABO}$ incompatibility and reproductive failure; possibility of incompatibility of antigen present in red cell membrane of husband and wife may play some role in abortions. ${ }^{6}$

Another study in India in 2009-Couple combinations having $\mathrm{O}$ type wives, $\mathrm{A}$ or $\mathrm{B}$ type husbands showed maximum fetal loss. Abortion is higher in A type husband and $\mathrm{O}$ type wife. Stillbirths higher in A type husband and B type wife. ${ }^{7}$ Total pregnancy wastage was higher in $\mathrm{ABO}$ incompatible mating $(24.59 \%)$ than compatible mating $(8.45 \%)$. Positive direct Coombs test and positive family history of neonatal jaundice or previous abortion strongly predict $\mathrm{ABO}$ incompatibility. ${ }^{8,9}$

Bilirubin level $>12 \mathrm{mg} / \mathrm{dl}$ for full term infant is worrisome-hyperbilirubinemia associated with neurological abnormalities, hearing loss and motor abnormalities. The diagnosis of ABO incompatibility is with onset of hyperbilirubinemia within 24 hours of birth, fetomaternal AO incompatibility, laboratory evidence of erythrocyte sensitization i.e. positive DCT, nevertheless a 
negative DCT can't rule out $\mathrm{ABO}$ incompatibility and exclusion of other causes of early onset of jaundice like G6 PD deficiency and Rh isoimmunization.

Management: New modalities like improved phototherapy and IVIgG therapy altered clinical course of the disease. ${ }^{10}$ IVIgG therapy may reduce the need for exchange transfusion. ${ }^{11}$ An exchange transfusion is necessitated only 1 in 1000 to 1 in 4000 pregnancies.

\section{CONCLUSION}

Early detection with high level of suspicion in $\mathrm{ABO}$ incompatible couples should help us avoid HDFN in developing countries. Proper awareness and screening measures can help in early management and to avoid catastrophes in new-born.

Funding: No funding sources

Conflict of interest: None declared

Ethical approval: Not required

\section{REFERENCES}

1. Chavez GF, Mulinare J, Edmonds LD. Epidemology of Rh haemolytic disease of the newborn in the United states. J Am Med Assoc. 1991;256:3270-4.

2. Roberts IA. The changing face of haemolytic disease of the newborn. Early Human Develop. 2008;84(8):515-23.

3. Thakral B, Agrawal SK, Krishan Dhawan H, Saluja K, Dutta S, Marwaha N. First report from India of haemolytic disease of newborn by anti-c and anti-E in $\mathrm{Rh}$ (D) positive mothers. Hematol. 2007;12(5):377-80.

4. Wu KH, Chu SL, Chang JG, Shib MC, Peng CT. Haemolytic disease of the newborn due to maternal irregular antibodies in the Chinese Populat Taiwan. Transf Med. 2003;13:311-4.

5. Schaap T, Shemer R, Palti Z, Sharon R. ABO incompatibility and reproductive failure. I. Prenatal selection. Am J Human Genet. 1984;36(1):143.

6. Malekasgar AM. ABO blood group prevalence in spontaneously repeated abortion. Turk J Haematol. 2004;2004(21):181-7.

7. Soni N, Mukherjee BM. A study on foetal wastage and $\mathrm{ABO}$ blood groups incompatibility among the Gonds of Garriyaband, Chhattisgarh, India. Anthropol. 2009;11(3):229-31.

8. Ogunlesi TA, Dedeke IO, Adekanmbi AF, Fetuga $\mathrm{MB}$, Ogunfowora OB. The incidence and outcome of bilirubin encephalopathy in Nigeria: a bi-centre study. Niger J Med: J National Assoc Resi Doctors Niger. 2007;16(4):354-9.

9. Richon J, Streiff F, Genett B, Landes P, Brunel G, Raffoux $\mathrm{C}$, et al. Value of the Coombs-Bromeline test in $\mathrm{ABO}$ feto-maternal blood incompatibilities. Bullet Federat Societ Gynecol Obstet French Lang. 1970;22(5):533-7.

10. Onesimo R, Rizzo D, Ruggiero A, Valentini P. Intravenous immunoglobulin therapy for anti-E hemolytic disease in the newborn. J Maternal-Fetal Neonat Med. 2010;23(9):1059-61.

11. Nasseri F, Mamouri GA, Babaei H. Intravenous immunoglobulin in $\mathrm{ABO}$ and $\mathrm{Rh}$ hemolytic diseases of newborn. Saudi Med J. 2006;27(12):1827-30.

Cite this article as: Nagashree $U$, Swetha $P$, Manohar S, Parthasarathy LK. ABO incompatibility: its impact on pregnancy and neonate. Int J Reprod Contracept Obstet Gynecol 2019;8:766-8. 